ЧЕРНЯВСКИЙ Владимир Андреевич профессор кафедры музыковедения, композиции

и методики музыкального образования

Краснодарского государственного института культуры

Краснодар, Российская Федерация

Vladimir A. CHERNYAVSKY

Prof., Department of Musicology, Composition and Methods of Music Education, Krasnodar State Institute of Culture,

Krasnodar, Russian Federation vladanch@yandex.ru

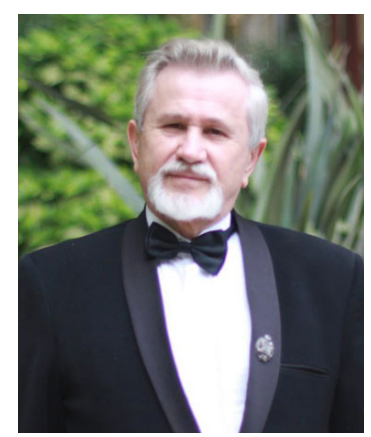

УДК [78:008-043.5]:37

РНТИ 18.41 .91

ВАК 24.00.01

\section{Взаимодействие музыкальных культур \\ в контексте современных проблем образования}

\section{Interaction of Musical Cultures in the Context of Modern Problems of Education}

Статья посвящена актуальной проблеме взаимодействия музыкальных культур в многонациональных регионах юга России. Автор рассматривает особенности традиционной музыки Ростовской области, Ставрополья, Астрахани, Кубани, Карачаево-Черкессии, Адыгеи и подчёркивает, что её органичное вхождение в академическое искусство происходило в специализированных учебных заведениях - музыкальных училищах и музыкальных педагогических институтах. Привлекавшиеся для работы в них педагоги, переплавляя в единое художественное целое местный фольклор и традиции академической музыки, создавали благоприятные условия для формирования нового поколения музыкантов, в произведениях которых находит свое подлинное воплощение диалог культур. Этот опыт, приходит к выводу автор, может быть взят на вооружение современной системой музыкального образования, в связи с чем изучение вопроса не должно прекращаться.

Ключевые слова: музыкальное образование, культура, южный регион, музыкальный фольклор.

В условиях глобализирующегося мира, занятого поиском общей платформы для культурного диалога, музыка оказывается одним из ярчайших образцов межкультурного взаимодействия. С этой точки зрения музыкаль- ное наследие России, которое отличается многообразием национальных школ, может рассматриваться как своего рода опытная лаборатория, в которой происходит непрестанное взаимовлияние одной культуры на другую, 
сопровождающееся их неизменным обогащением. В числе наиболее ярких представителей диалога культур назовем Б. В. Асафьева, осуществившего взаимодействие русского и татарского мелоса («Бахчисарайский фонтан»), М. А. Балакирева, представившего диалог русской и кабардинской музыкальных культур («Исламей»), Е. Г. Брусиловского, показавшего своеобразие русского и казахского фольклора («Кыз-Жибек»), М. П. Мусоргского, опирающегося на русские и украинские песни («Сорочинская ярмарка»).

Помимо локального диалога, развиваемого в рамках российской культуры, глобальный диалог, инициируемый взаимодействием Запада и Востока, обнаруживает себя в творчестве М.И. Глинки («Руслан и Людмила»), А. П. Бородина («Князь Игорь»), Н.А. Римского-Корсакова («Золотой петушок», «Шахерезада»). Очевидно, что в своих произведениях наши соотечественники не просто обращались к восточным темам, подчёркивая характерную интонацию, ладовые тяготения или же ритмические изыски, но и создавали новый образ Востока, музыкальная палитра которого была особенно притягательной, поскольку в качестве «художника» выступал представитель русской культуры.

В данном контексте особого внимания заслуживает опера А.П.Бородина «Князь Игорь», в которой композитор создал обобщенный образ Востока с его орнаментальностью, терпкостью мелодической линии и пряными гармониями. Не случайно фрагменты оперы, связанные с половцами и приметами половецкой культуры, так пленительны для современных музыкантов, в том числе представителей популярной массовой музыки. Достаточно назвать сборник «The Rapsody Overture», в одной из композиций которого его автор Warren Griffin объединил рэп и русскую классику (имеется в виду хор «Улетай на крыльях ветра» из оперы Бородина «Князь Игорь»).

Знаменательно, что заложенная несколько столетий назад традиция продолжается и в наше время. Для аргументации данной позиции остановимся на специфике музыкальной культуры юга России, характеризующейся плодотворным взаимодействием ака- демической музыки и фольклора. Речь идет о традиционной музыке, место бытования которой - Ростовская область, Ставрополье, Астрахань, Кубань, Калмыкия, Карачаево-Черкессия, Адыгея. Она представлена в таких музыкальных образцах, как:

- казачьи песни,

- русские народные песни,

- песни горцев,

- армянские наигрыши на свадебных торжествах,

• калмыцкие народные песнопения,

- песни волжских рыбаков,

- песни немцев Поволжья.

Становление культуры диалога, посредством которого песня и инструментальный наигрыш как неотъемлемые составляющие жизни населения южных регионов нашей страны органично входили в академическое искусство, происходило в специализированных учебных заведениях - музыкальных училищах и музыкальных педагогических институтах. Для их полноценного функционирования привлекались лучшие педагоги, получившие образование в столичных вузах. Приобщаясь к мелосу коренных народов, а также тех, для кого, подобно волжским немцам, русские земли стали второй родиной, вовлекая в творческую практику народные инструменты (доул, дудук, пандури тар, шви, зурна, ширванский тамбур, кавказкая гармоника, шичепшин, дала фаендыр, ребаб, саз и т.д.), переплавляя в единое художественное целое местный фольклор и традиции академической музыки, наследники русской школы создавали благоприятные условия для формирования нового поколения музыкантов.

Так, в 1968 г. в Ростове-на-Дону был открыт Музыкально-педагогический институт (впоследствии Ростовская государственная консерватория им. С. В. Рахманинова). В его стенах под руководством опытных наставников студенты - будущие композиторы и музыковеды, а также исполнители осваивали богатейшую культуру родного края, вырабатывая навыки профессионального мастерства. Композиторы приобщали к музыкальным традициям своим творчеством - обработками народных песен, вариациями на популярные в народе мелодии, создавали крупные музы- 
кальные произведения на региональном материале (сюиты, поэмы, симфонические танцы). Исполнители пропагандировали создаваемые в процессе сочинения музыки произведения авторов региона, а музыковеды посредством исследований, раскрывающих уникальность народной музыки, ее непреходящую ценность и подлинность выражаемого в ней духа народа, обеспечивали прирост теоретического знания о профессиональной и народной региональной музыке.

Обобщая результаты совместной работы педагогов и студентов, обогатил свой репертуар после реорганизации в 1970 г. Ансамбль донских казаков (руководитель А.Н. Квасов), выступления которого вызывали неизменный восторг со стороны самой требовательной слушательской аудитории. В целом творчество ростовских композиторов представлено довольно широко: от песни до симфонии. Свидетельством жанрового многообразия служат следующие данные. Ростовский композитор А. П. Артамонов (1906-1994) написал 13 симфоний, Л. П. Клиничев (1937) - балет «Тихий дон» и оперу «Цыгане», В.С. Ходош (1945-2016) - оперы «Беззащитное существо», «Ведьма», «Медведь», созданные по мотивам чеховских рассказов, А. И. Кусяков (19452007) - симфонию «Осенний ноктюрн» и др.

С появлением в 1969 г. консерватории в городе Астрахани оказался возможным культурный диалог, связавший музыку волжских татар, калмыков, казахов, немцев. Значительный пласт бытующего в данном регионе фольклора, записанного в рамках научно-исследовательских экспедиций на магнитофонную пленку и впоследствии зафиксированного в нотном тексте посредством расшифровки, осуществленной музыковедами, оказался в творческой копилке композиторов региона. В частности, благодаря деятельности музыковедов стало доступно наследие казахского музыканта Курмангазы Сагырбайулы (19181989), который в своем творчестве обращался к образам, сохранившимся в легендах и народных сказаниях. Богатое творческое наследие оставили астраханские композиторы А. И. Блинов (1945-2006), Ю. П. Гонцов (1946). Обращение к татарской музыке, отмеченной проникновенным лиризмом, необычайной нежностью мелодического языка, танцевальностью, истоки которой в гармошечных наигрышах, позволило астраханскому композитору-самородку Тельману Сармульдиеву создать фортепианную сюиту «Лотос» (1970).

Многие выпускники Астраханской консерватории после окончания вуза стали работать в соседней Калмыцкой АССР, что положительно сказалось не только на музыкальном творчестве, но и на изучении песенного и танцевального наследия потомков Великого Джангара. Неповторимость калмыцкого фольклора, древность культуры, сохранившейся до наших дней, находят свое воплощение в песнях Утт дун (длинная песня) и Ахр дун (короткая песня), возраст которых свыше шестисот лет. Именно Утт дун и Ахр дун отражают многовековую историю сочинившего их народа, жизнь кочевников с особенностями их языка, мелодии, танца и сказок (последние стоят на втором месте после сказок Индии в мире). Музыковеды и композиторы, познакомившиеся с творчеством этого народа, единодушны в оценке своеобразия калмыцкой песни. Отличаясь богатством ладов (миксолидийский, дорийский, диатоника и пентатоника), калмыцкая песня, как правило, одноголосна. Несмотря на редкие кварты в подголоске, эта музыка лишена гармонии, что создает определенные трудности в процессе инструментальных обработок калмыцких песен. Тем не менее профессиональный композитор П. О. Чонкушов (1930-1999) справился с данной задачей: расположив народную мелодию по вертикали, он таким образом создал базу для ее музыкально-гармонического развития.

Взаимопроникновение разных музыкальных культур хорошо заметно на примере калмыцкой народной танцевальной мелодии чичирдык, рождённой в одной из станиц близ Ростовской области, которую населяли выходцы из Украины и находящиеся на царской службе калмыки. Она воплощает собой соединение украинского и калмыцкого фольклора. Восточный дух со временем вытеснил из этой мелодии некогда присущий ей европейский характер украинского гопака. Но его приметы всё ещё опознаются в построенном на субдоминантовой гармонии припеве. В целом анализ современной песенной культуры калмы- 
ков позволяет утверждать, что ее становление проходило под влиянием русских и украинских песен, а также музыкального творчества Поволжья и Северного Кавказа, в случае, когда эти народы жили в территориальной близости друг к другу [4].

В 1903 г. в городе Ставрополе было открыто музыкальное училище. Важность этого события обусловлена тем, что Ставрополье регион, в котором в тесной взаимосвязи находятся терские и линейные казаки, туркмены, о значительности диаспор которых говорит название одного из районов Ставрополя (Туркменский район), армяне, карачаевцы, черкесы, даргинцы. Песенная и танцевальная культура этого региона обращает на себя внимание яркой самобытностью. Она уходит корнями в период создания защитной линии от Тамани до Георгиевска, осуществлённого в эпоху А. В. Суворова. На протяжении десятилетий, начиная с 50-х гг. XX в. Ставропольское хоровое общество (руководитель А.И.ККуцепал) привлекало преподавателя Ставропольского музыкального училища Л. Якоби, музыковедов института им. Гнесиных Л. Антипову, Т. Латышеву, И. Колотыгину, И. Шлюгера для записи народных песен Ставрополья. Собранный материал был опубликован таким образом, что 100 народных песен увидели свет в 2005 г., еще 100 - в 2007-м, из них 50 песен были записаны Е. Колесниковым. Столь ценное для культуры Ставрополья издание было осуществлено композитором В. А. Чернявским [5], [6].

Собиратель фольклора терских казаков Ефим Колесников (XIX-XX вв.) очень точно определил влияние на песни казаков горских мелодий. «Пение хоров терского казачества,писал он,- отличается высоким тоном, тесситура крайняя для теноров и очень низкая для басов, громадное влияние имеет горская интонация, появился европейский дух, привнесённый офицерами, которые работали с хорами» [2, с. 34].

Открытие на Кубани так называемых классов РМО (Русское музыкальное общество), инициируемое А. Д. Бигдаем [1], было весьма примечательным вследствие того, что Краснодарский край во все времена был и остаётся центром музыкального притяжения многих народов, привнесших в местный колорит характерную для каждого из них неповторимость. Яркий след на музыкальной карте Кубани оставили черноморские казаки - выходцы из Украины. Благодаря армянам, грекам, ассирийцам, адыгейцам сложилась особая, характерная только для данного региона музыкальная культура. Ее сохранение и приумножение стало делом всей жизни руководителя Кубанского казачьего хора Г. М. Концевича (1863-1937), который собрал более 300 песен кубанских казаков и 300 песен и наигрышей адыгейцев. Позже эту миссию возложил на себя В. Г. Захарченко (1939) - нынешний художественный руководитель хора, пропагандист кубанской песни, известной своим широким диапазоном и исторической памятью, пламенным характером и тонким лиризмом.

Сегодня ядро Краснодарского отделения Союза композиторов России составляют профессионалы, свободно владеющие самыми разными музыкальными жанрами, в которых находит свое воплощение диалог культур. В частности, в творчестве В.А.Чернявского (1947) мы находим оперу-действо «Казачий кордон», соединившую в себе русский, украинский и адыгский мелос, а также балет «Легенда синих гор», в котором доминируют интонации, характерные для калмыцкого фольклора. В творчестве кубанского композитора М. В. Водопьянова-Беруашвили (1960) -ораторию «Исторические картины Кубани» на стихи И. Вараввы, в которой можно услышать песенные интонации русского казачества, адыгских абадзехов, аланов. Композитор В. М. Волченко (1946) широко использовал украинский и казачий мелос в увертюре «Край привольный казачий» для оркестра русских народных инструментов, в «Кубанской рапсодии» и «Казачьей кавалерийской».

Развиваемая и закрепляемая в профессиональной среде установка на межкультурное взаимодействие, поддерживаемая администрацией и коллективом преподавателей Краснодарского музыкального училища и Консерватории Краснодарского государственного института культуры находит свое продолжение в работе выпускников. Имеются в виду учителя общеобразовательных школ, отвечающие за качество преподавания предмета «Кубано- 
ведение», а также преподаватели детских музыкальных школ и школ искусств. Так, например, в диссертационном исследовании Е. Е. Рыбалко «Толерантность как принцип культурной политики» [3], которое прошло защиту в стенах Краснодарского государственного института культуры и искусства (ныне - Краснодарский Государственный институт культуры) автор делится опытом изучения в рамках теоретических дисциплин фольклора адыгов, армян, казахов и др., представленного на уровне песен обрядового цикла.

Bсе это позволяет новому поколению россиян приобщаться к традициям своего народа с полным осознанием того, что знакомство с культурой другого народа с неизменностью обогащает собственную культуру, расширяя границы мировосприятия.

\section{Vladimir A. CHERNYAVSKY \\ Interaction of Musical Cultures in the Context of Modern Problems of Education}

Abstract. The article is devoted to the urgent problem of the interaction of musical cultures in the multinational regions of Southern Russia. In the context of the growing globalization, the search for ideas that can become the basis for intercultural dialogue is becoming relevant. In these conditions, music can be considered as the clearest example of a powerful resource for creating and strengthening the space of interethnic interaction. Russian musical heritage is enormous in its characteristics, distinguished by the wealth of national schools. This heritage is a unique laboratory in which distinctive cultures constantly experience mutual influence thus enriching each other. The author notes that Russian composers constantly turned to Oriental themes not only reflecting the corresponding musical specifics, but also creating a new image of the East in the eyes of their compatriots, acting as "artists" carrying Russian culture. Currently, this tradition continues, which is shown by an example of the musical culture of the South of Russia, whose development reflects the constant interaction of academic music and folklore. The culture of dialogue, which made the integration of traditional music and academic art possible, originated in specialized educational institutions. The first of these institutions was the Music and Pedagogical Institute (later Rostov State Rakhmaninov Conservatoire), which trained composers whose works expressed all musical forms and genres. The joint work of teachers and students in the early 1970s positively reflected in the work of the Ensemble of Don Cossacks. The founding of Astrakhan State Conservatory (1969) became an important link in the formation of the space for cultural interaction between the peoples of the region (Kalmyks, Volga Germans, Kazakhs, Volga Tatars, etc.). Of great importance for the work of local composers were folklore works recorded on tape during ethnographic expeditions and then decrypted in the form of musical notation. Of considerable importance was the activity of graduates of Astrakhan Conservatory in the neighboring Kalmykia. According to composers and musicologists, the traditional music of the Kalmyk people is notable for its significant originality. One example of cultural interaction in the musical sphere is the Kalmyk dance melody Chichirdyk, which appeared in one of the villages populated by Kalmyks and Ukrainians. In Stavropol Krai, the opening of Stavropol School of Music in 1903 had a positive impact on the local traditional song and dance culture. The musical tradition of this region began to form during the period of active development of the region by the East Slavic population since the end of the 18th century. Krasnodar Krai is the center that has been attracting many ethnic groups, each of which brought its own unique shade to the local musical palette. The carriers of ethnic cultures that actively influenced the formation of the musical picture of the region were the Adyghe, Black Sea Cossacks, Armenians, Greeks, Assyrians and many other peoples. Currently, the Krasnodar Branch of the Union of Composers of Russia includes professionals who are fluent in various genres of music and embody the ideas of dialogue of cultures in the form of musical works.

Keywords: musical education, musical composition, culture, South of Russia, musical folklore, academic music, Rostov Conservatoire, Astrakhan Conservatory, Kalmykia, Stavropol Krai, Krasnodar Krai. 


\section{Использованная литература:}

1. Аникиенко С. В. М. Ф. Гнесин в Краснодаре: сквозь призму времени: монография. Краснодар: ИП Вольная, 2017.

2. Колесников Е. Песенное искусство терских казаков. Ставрополь: [б. и.]. Семейный архив Е. Колесникова (рукопись, 1960-е гг.).

3. Рыбалко Е. Е. Толерантность как принцип культурной политики: региональный аспект: автореф. дис. ... канд. культурологии: 24.00.01 - теория и история культуры. Краснодар, 2012.

4. Цебеков Л. Сто калмыцких народных песен. Элиста: Калмыцкое кн. изд-во, 1991.

5. Чернявский В. А. Казачьи песни Ставрополья. Ставрополь: Интеллект; Юркит, 2007.

6. Чернявский В. А. Венок Ставрополья: сборник народных песен. Краснодар: Эоловы струны, 2005.

\section{References:}

1. Anikienko, S.V. (2017) M.F. Gnesin v Krasnodare: skvoz' prizmu vremeni [M.F. Gnesin in Krasnodar: through the prism of time]. Krasnodar: IP Vol'naya.

2. Kolesnikov, E. (c. 1960s) Pesennoe iskusstvo terskikh kazakov [The song art of the Terek Cossacks]. Stavropol: [s.n.]. Family archive of E. Kolesnikov (manuscript, 1960s).

3. Rybalko, E.E. (2012) Tolerantnost' kak printsip kul'turnoy politiki: regional'nyy aspekt [Tolerance as a principle of cultural policy: A regional aspect]. Abstract of Culture Studies Cand. Diss. Krasnodar.

4. Tsebekov, L. (1991) Sto kalmytskikh narodnykh pesen [One hundred Kalmyk folk songs]. Elista: Kalmytskoe kn. izd-vo.

5. Chernyavskiy, V.A. (2007) Kazach'i pesni Stavropol'ya [Cossack songs of the Stavropol region]. Stavropol: Intellekt; Yurkit.

6. Chernyavskiy, V.A. (2005) Venok Stavropol'ya: sbornik narodnykh pesen [The wreath of the Stavropol region: A collection of folk songs]. Krasnodar: Eolovy struny.

\footnotetext{
Полная библиографическая ссылка на статью:

Чернявский, В. А. Взаимодействие музыкальных культур в контексте современных проблем образования [Электронный ресурс] / В. А. Чернявский // Наследие веков. - 2019. - № 3. - С. 106-111. DOI: 10.36343/SB.2019.19.3.011
}

Full bibliographic reference to the article:

Chernyavsky, V. A. (2019) Interaction of Musical Cultures in the Context of Modern Problems of Education. Nasledie vekovHeritage of Centuries. 3. pp. 106-111. (In Russian). DOI: 10.36343/SB.2019.19.3.011 